\title{
PRACE DYPLOMOWE O ŚW. AUGUSTYNIE PISANE NA KUL
}

Większość prac dyplomowych o św. Augustynie $i$ na temat nauk1 św. Augustyna, napisanych na Katolickim Uniwersytecie Lubelskim, pochodzi z okresu po II wojnie światowej. Aktualnie w Bibliotece KUL-u przechowywane sa 24 rozprawy, z czego 2 - habilitacyjne; 3 - doktorskie; 5 - licencjackich 114 magisterskich. Nie jest to wi ęc Imponująca cyfra. Nie moźna jednak wykluczyć faktu, że prace o tej tematyce pisano na KUL-u również w okresie międzywojennym. Brakuje ich jednak w Bibliotece.

Najwięcej prac dyplomowych napisano na Wydziale Teologicznym - 12. Na Wydziale Filozoficznym powstało 8 rozpraw, a na iydziale Humanistycznym 4 prace.

Plerwsza rozprawa habilitacyjna pt. "Bóg jako Dobro Najwyższe według św. Augustyna" jest autorstwa ks. dra Stanisława Kowalczyka, obecnego profesora KUL. Praca została przedstawiona w $1968 \mathrm{r}$. , a wydrukowana w r. 1980 /w: Opera Philosophorum Medii Aevi Textus et Studia, t. 3: Z filozofii św. Augustyna i św. Bonawentury, Warszawa 1980, 31-158/. Celem omawianej rozprawy było przedstawienie augustyńskiej teorii Summi Boni jako jednego $z$ istotnych ogniw w twórczym rozwoju chrześcijańskiej filozofii Boga. Teoria ta nie była dotąd opracowana. Pracaks. Kowalczyka nie posiada charakteru wyłącznie historycznego, ale historyczno-systematyczny. Poruszono w niej równiez takie problemy, które interesuja systematyka,jak np. stosunek filozofii do teologii, problem natury Bożej. Rozprawa nie ogranicza się do ekspozycji poglądów św. Augustyna, ale na bazie jego systemu postawione i rozpracowane zostały równiez takie problemy, których on nie stawiat.

Druga rozprawa habilitacyjna pt. "Dialog świętego Augustyna ze śviatem pogaúskim w świetle jego korespondencji" powstała na Wydzlale Teologicznyri KUL w 1987 roku. Jej autorem jest ks. dr Augustyn Lickmann, adiunkt naszego Uniwersytetu. W przedmowie pisze on: "Wyśl o wyborze i opracowaniu tematu /.../ zrodziła się 7 kirietnia $1980 \mathrm{r}$. w Gdańsku pod wpływem /.../ rozmowy z jednym $z$ najwybitniejszych znawców biskupa Hippony, Księdzem Pro- 
fesorem Wacławem Eborowiczen /.../"/s.9/. Dlaczego ks. Eckmann zają się korespondencja śt. Augustyna? otóz - jak pisze we Wstępie - "iorespondencja jest świadectwen jego związków z najwybitniejszymi ludźmi zarówno Kościoła, jair i Państwa, stanowi uwiecznienie szacunku, jaki dla jego osobistych cnót i zalet okazywali wu nawet jego przeciwnicy, dowodzi zaupania, z jakin zwracano sie do niego ze wszystkich stron w najrozmaitszych sprawach, ażeby poznać jego poyląd albo potwierdzenie słuszności czy niesłuszności własnych sądów, unaocznia niezmordowana działalność Augustyna, który wśród cięzaru licznych spraw i prac miał czas na wyjaśnienie wszystkich problemów swych korespondentów" /s. 16/. Ponicwaz praca ukazała się drukiem, dlatego odsyłam zainteresowanych do zapoznania sie z nią.

Praca doktorska ks. Kyszarda Cyrklaffa, napisana na Wydziale l'eologicznyia i obroniona w $1973 \mathrm{r}$., zajmowała się "Koncepcją tolerancji wewnatrzkościelnej w pismach antydonatystycznych św. Augustyna". Autor rozprawy rozwinaz problem tolerancji, o której pisał wcześniej pod innym katem w pracy licencjackiej pt. "Tolerancja religijna w ujęciu św. Augustyna".

Dwie następne rozprawy doktorshie powstały na Wydziale Filozoficznym. Pierwsza z nich została napisana przez Jana Puzie, który zajał sie "Teoria poznania zmysłowego u św. Augustyna", a druga przez ks. Julisława Lukomskiego, który podjął się opracowania oryginalnero zagadnienia, mianowicie: "Augustyńska teoria rozwoju organizmów w świetle współczesnego ewolucjonizmu".

Większość prac licencjackich i magisterskich zajmuje sie wybranyı 1 zagadnieniami nauczania św. Augustyna. Dla przykładu kilka tytułów:

- "Prymat papieża w Kościele na tle eklezjologil św. Augustyna" /Czesław Holecki/;

- "O karze "poena mitissima" dzieci zrarłych bez chrztu świętego według św. Augustyna" /O. Pacyik Schwlerz/;

- "reocentryzm dziejów zbawienia według "De Civitate Dei" św. Augustyna"/Zuzisław rłustochowicz/;

- "Nauka o powściagliıości w dzlele św. Alugustyna "De continentia"/Kazimierz Bidziński/;

- "Zagadnienie poroju u św. Augustyna" /Stanisław Lysiak/;

- "Nauczanie sw. Augustyna o cierọliwości chrześcijańskiej w swietle dziela "De patientia" /Sławomir Lis/; 
- "Wolnośs a prawda w koncepcjach człowieka Augustyna 1 Karola Wojtyły" / Adan Szwed/.

Najczęściej opracowywanym dziełem św. Augustyna jest "De Civitate De1". Inny charakter od pozostalych prac dyplomowych ma rozprawa magisterska Jerzego Pałuckiego z 1980 roku. Autor zajaz się "Recepcją nauki św. Augustyna na kamach "Ateneum Kapłarískiego" w latach 1909-1980".

Od przedstawionych powyżej rozpraw różnia się prace pisane na Wydzlale Huinanistycznym, na sekcji filologil klasycznej, a więc o charakterze filologicznym. Trzeba tu wymienić 2 prace magisterskie: Leszka Kusińskiego z 1985 r - "Znaczenie wyrazów "fides" 1 "fidelis" w "De Trinitate" św. Augustyna" 1 Jana Krzemińskiego z 1973 ro = "Swięty Augustyn - Wybór Listów. Wstęp Tłumaczenie - Kore ntarz"。

Reasumując to krótkie przedstawienie prac dyplomowych o św. Augustynie pisanych na KUL-u należy zaznaczyć, ze wiele rozpraw; tak habilitacyjnych 1 doktorskich, jak licencjackich 1 magisterskich, nie zajmujących się wprost Bisisupem Hippony 1 jego nauka, posiada fragmenty, $i$ to nieraz spore, traktujace o św. Augustynie. Przykładem może być tutaj praca licencjacka dzisiejszego biskupa prof. dra hab. Alfonsa Nossola pt. "Nauka Jana IIessena o augustyriskięj teorii poznania Boga", napisana pod kierunkiem ks. prof. dra hab. Wincentego Granata 1 obroniona w 1959 roku. Podobnie o św. Augustyna "zahacza" np. praca magisterska ks. Andrzeja Firosza, pisana pod kierunkiem ks. bpa doc. ara hab. Jana Śrutwy pt. "Organizacja katechezy w APryce Lacińskiej w epoce św. August yna".

$$
\text { Ks. Janusz Dyl SAC - Lublin }
$$

\section{DIE AN DER KATHOLISCHEN UNIVERSITÄT IN LUBLIN GESCHRIEBENEN ARBEITEN UBER DEN HEILIGEN AUGUSTIN}

\section{/Zusammenfassung/}

Die meisten Arbelten uber den heiligen Augustin stammen aus der Zeit nach dem 2. Weltkrieg. Gegenwätig werden in der Universitutsbibliothek 24 Abhandlungen aufbewahrt, darunter $2 \mathrm{Ha-}$ bilitationsschrift, 3 Doktorarbeiten, 5 Lizentiatsschriften und 14 Lagisterarbeiten. Die Mehrzahl der Diplomarbeiten wurde in der theologischen Falsultat geschrieben - 12. In der philosophischen Fakultat entstanden 8 Abhandlungen und in der humanist ${ }_{-\infty}$ schen Fakultat 4 Arbeiten. Es sel auch betont, dass zahlreiche Diplomarbeiten, die sich weder mit dem heiligen Augustin nach 
mit seiner Lehre befassen, viele diese Gestalt betreffende Fragmente enthalten. 